Article

\title{
Electrochemical Performance and in Operando Charge Efficiency Measurements of Cu/Sn-Doped Nano Iron Electrodes
}

\author{
Alagar Raj Paulraj ${ }^{1, * \mathbb{C}}$, Yohannes Kiros ${ }^{1}$, Mylad Chamoun ${ }^{2}$, Henrik Svengren ${ }^{2}$, Dag Noréus ${ }^{2}$, \\ Mats Göthelid ${ }^{3}{ }^{(0)}$, Björn Skårman ${ }^{4}$, Hilmar Vidarsson ${ }^{4}$ and Malin B. Johansson ${ }^{5}(\mathbb{C}$ \\ 1 Department of Chemical Engineering, KTH Royal Institute of Technology, SE-100 44 Stockholm, Sweden; \\ yohannes@kth.se \\ 2 Department of Materials and Environmental Chemistry, Stockholm University, SE-106 91 Stockholm, \\ Sweden; mylad.chamoun@mmk.su.se (M.C.); henrik@svengren.se (H.S.); dag.noreus@mmk.su.se (D.N.) \\ 3 Material Physics, KTH Royal Institute of Technology, SCI, S-164 40 Kista, Sweden; gothelid@kth.se \\ 4 Höganäs AB, SE-263 83 Höganäs, Sweden; Bjorn.Skarman@hoganas.com (B.S.); \\ Hilmar.Vidarsson@hoganas.com (H.V.) \\ 5 Division of Physical Chemistry, Department of Chemistry, The Ångström Laboratory, Uppsala University, \\ P.O. Box 523, SE-75120 Uppsala, Sweden; malin.johansson@kemi.uu.se \\ * Correspondence: arpau@kth.se
}

Received: 19 November 2018; Accepted: 6 December 2018; Published: 21 December 2018

\begin{abstract}
Fe-air or Ni-Fe cells can offer low-cost and large-scale sustainable energy storage. At present, they are limited by low coulombic efficiency, low active material use, and poor rate capability. To overcome these challenges, two types of nanostructured doped iron materials were investigated: (1) copper and tin doped iron (CuSn); and (2) tin doped iron (Sn). Single-wall carbon nanotube (SWCNT) was added to the electrode and $\mathrm{LiOH}$ to the electrolyte. In the $2 \mathrm{wt}$ \% $\mathrm{Cu}+2 \mathrm{wt}$. \% Sn sample, the addition of SWCNT increased the discharge capacity from 430 to $475 \mathrm{mAh} \mathrm{g}^{-1}$, and charge efficiency increased from $83 \%$ to $93.5 \%$. With the addition of both SWCNT and $\mathrm{LiOH}$, the charge efficiency and discharge capacity improved to $91 \%$ and $603 \mathrm{mAh} \mathrm{g}^{-1}$, respectively. Meanwhile, the $4 \mathrm{wt}$. \% Sn substituted sample performance is not on par with the $2 \mathrm{wt.} \% \mathrm{Cu}+2 \mathrm{wt}$. \% Sn sample. The dopant elements $(\mathrm{Cu}$ and $\mathrm{Sn}$ ) and additives (SWCNT and $\mathrm{LiOH}$ ) have a major impact on the electrode performance. To understand the relation between hydrogen evolution and charge current density, we have used in operando charging measurements combined with mass spectrometry to quantify the evolved hydrogen. The electrodes that were subjected to prolonged overcharge upon hydrogen evolution failed rapidly. This insight could help in the development of better charging schemes for the iron electrodes.
\end{abstract}

Keywords: iron electrodes; $\mathrm{Cu}$ and Sn-doped iron; SWCNT and LiOH additives; charge efficiency; hydrogen evolution; GC-MS analysis

\section{Introduction}

Consumption of energy produced through fossil fuels is considered to be one of the major contributors to global warming [1]. To achieve a sustainable energy system, many nations have initiated subsidies to add wind and solar power generation to the electricity grid. The intermittent character of these renewable energy sources requires, however, large-scale energy storage systems to handle the load fluctuations. At present, only $1 \%$ of the total energy produced is stored by the pumped hydroelectric storage plants, which offers the lowest cost among the available storage solutions today $(\$ 180-200 / \mathrm{kWh})$, and accounts $98 \%$ of the installed storage systems [2,3]. On the other hand, 
electrochemical energy storage systems (EES) have several advantages such as flexibility in design and size, with high efficiency and can be installed either close to the generation or at the consumer sites [3,4].

Among different battery chemistries, only the Fe-air battery meets the performance ( $80 \%$ current efficiency and 5000 cycles) and capital cost requirement $(\$ 100 / \mathrm{kWh})$ as prescribed by the United States Department of Energy [5]. The Swedish National Development Corporation and the Westinghouse corporation had been developing this system with an energy density of 80 and $140 \mathrm{Wh} \mathrm{kg}^{-1}$, respectively, for traction application [6,7]. Although the energy and power densities were not enough to meet the performance targets for the traction application, their performance is compelling enough for the grid-scale energy storage requirements such as safety, cost, and performance [7]. However, the Fe-air battery has some problems such as low current efficiency, low material use, and poor discharge rate $[6,8-10]$.

Operation of the iron electrode involves two reaction stages during their charge and discharge, as shown in reactions Equations (1) and (2). The first stage involves a two-electron $\mathrm{Fe}$ and $\mathrm{Fe}(\mathrm{OH})_{2}$ redox couple, while following this stage, $\mathrm{Fe}(\mathrm{OH})_{2}$ forms $\mathrm{Fe}(\mathrm{OOH})$. The conventional iron electrode uses only the first discharge step, corresponding to $962 \mathrm{mAh} \mathrm{g}^{-1}$ of specific discharge capacity. Furthermore, the iron electrode is a good catalyst for the hydrogen evolution reaction. Its reversible thermodynamic potential is $-0.93 \mathrm{~V}$ vs. $\mathrm{Hg} / \mathrm{HgO}$, as shown in Equation (3). Consequently, the iron electrode undergoes self-discharge reaction under open cell configuration resulting in the accumulation of passive iron hydroxides, and also hydrogen evolution during charging [11].

$$
\begin{gathered}
\mathrm{Fe}+2 \mathrm{OH}^{-} \leftrightarrow \mathrm{Fe}(\mathrm{OH})_{2}+2 \mathrm{e}^{-} ; \mathrm{E}^{0}=-0.975 \mathrm{~V} \text { vs. } \mathrm{Hg} / \mathrm{HgO} \\
3 \mathrm{Fe}(\mathrm{OH})_{2}+2 \mathrm{OH}^{-} \leftrightarrow \mathrm{Fe}_{3} \mathrm{O}_{4} \cdot 4 \mathrm{H}_{2} \mathrm{O}+2 \mathrm{e}^{-} ; \mathrm{E}^{0}=-0.756 \mathrm{~V} \text { vs. } \mathrm{Hg} / \mathrm{HgO} \\
2 \mathrm{H}_{2} \mathrm{O}+2 \mathrm{e}^{-} \leftrightarrow \mathrm{H}_{2}+2 \mathrm{OH}^{-} ; \mathrm{E}^{0}=-0.93 \mathrm{~V} \text { vs. } \mathrm{Hg} / \mathrm{HgO}
\end{gathered}
$$

As a consequence of the self-discharge and hydrogen evolution, the iron electrode presents poor charge efficiency, low charge retention and low discharge capacity with decreased life cycle $[12,13]$. Additionally, the passive oxide and hydroxide phases gradually build up over time [12]. To overcome hydrogen evolution, sulfur additives are either added to the electrode formulation (e.g., $\mathrm{FeS}+$ $\mathrm{Bi}_{2} \mathrm{O}_{3}, \mathrm{Bi}_{2} \mathrm{~S}_{3}$ ) or to the electrolyte by addition of $\mathrm{Na}_{2} \mathrm{~S}, \mathrm{~K}_{2} \mathrm{~S}$, and organosulfur compounds [14-17]. The adsorbed sulfur depassivates the iron electrode and thereby it increases the electrode conductivity, rate capability and further poisons the active catalytic surfaces for the hydrogen evolution. Previous studies have shown that bismuth as an additive suppresses the hydrogen evolution by increasing the overpotential [18-20].

To circumvent the low active usage of the material as well as passivation inducing capacity decay, nano iron, nano iron-carbon composites and FeS materials have been used as active materials [21-29]. Notably, iron with graphene, MWCNT, amorphous carbon composites have shown to be producing increased redox activity and high capacity. However, these materials have presented rapid capacity decay, which is caused by nanoparticle agglomeration and by increased rate of hydrogen evolution [29-33]. Sundar Rajan et al. [18] demonstrated that carbon grafted iron delivered $400 \mathrm{mAh} \mathrm{g}^{-1}$ of specific discharge capacity (discharge rate $100 \mathrm{~mA} \mathrm{~g}^{-1}$ ). C.-Y. Kao et al. [10] reported that in the presence of $\mathrm{Cu}$ a high discharge capacity $\left(800 \mathrm{mAh} \mathrm{g}^{-1}\right)$ at $3200 \mathrm{~mA} \mathrm{~g}^{-1}$ was achieved. The results confirm that $\mathrm{Cu}$ and amorphous carbon enhances the iron discharge performance. Our recent work on copper substituted core-shell structured iron/iron carbide/carbon active material has also shown to maintain stable discharge capacity $\left(350 \mathrm{mAh} \mathrm{g}^{-1}\right)$ at higher discharge rate 100-350 $\mathrm{mA} \mathrm{g}^{-1}$ [34]. Chamoun et al. used stannate electrolyte additive, which resulted in high capacity at $400 \mathrm{mAh} \mathrm{g}^{-1}$ with $85 \%$ charge efficiency [35]. Here the thin layer of Sn deposits on the iron electrode is believed to suppress the $\mathrm{H}_{2}$ evolution. Therefore, amorphous carbon, $\mathrm{Cu}$, and $\mathrm{Sn}$ have the capability to enhance the iron electrode redox activity. 
In this work, we have used and studied nano/iron/carbon/Cu/Sn and nano/iron/carbon/Sn as two type of active materials for the iron electrode. We also investigated the effect of single-wall carbon nanotube (SWCNT) and $\mathrm{LiOH}$ on the iron electrode to maintain the performance of the charge and discharge capacities of these materials. This study aims to show that the particle agglomeration is prevented by the carbon layer, while $\mathrm{Cu}$ maintains the stable conductivity, whereas $\mathrm{Sn}$ suppresses the hydrogen evolution. We have achieved capacity as high as $600 \mathrm{mAh} \mathrm{g}^{-1}$ for the SWCNT with LiOH addition to the electrolyte. Furthermore, we investigated the effect of charge current density on the hydrogen evolution rate for different electrode formulations coupled with mass spectrometry. From this study, we have observed that high charge current density reduces the hydrogen evolution rate.

\section{Experimental Method}

Nano iron powders doped with copper and tin were obtained from Höganäs AB. In sample 1, denominated as CuSn, the elemental compositions were 2 wt. \% Cu, 2 wt. \% Sn, 23 wt. \% C and 73 wt. \% Fe. Sample 2 (Sn), consists of 4 wt. \% Sn, 24 wt. \% carbon and 72 wt. \% Fe. The composition of carbon was based on the thermogravimetric analysis (TGA) and energy-dispersive X-ray spectroscopy (EDX).

The powder samples were analyzed by X-ray diffraction (XRD) (Siemens Bruker D5000), equipped with a Co $\mathrm{K}_{\alpha}$ source $(30 \mathrm{~mA}, 40 \mathrm{kV})$. The phase identification was made on the EVA software, and the powder diffraction file (PDF 2) was used to identify the plane reflection. The morphologies of the powder samples were analyzed by Zeiss Ultra-55 scanning electron microscope (SEM), and transmission electron microscope (TEM) image was obtained by JEOL JEM-2100F. X-ray photoelectron spectroscopy (XPS) was investigated in a PHI Quantum 2000 scanning XPS microprobe with $\mathrm{Al} \mathrm{K} \alpha$ radiation as a source. The spot size was $0.1 \times 0.1 \mu \mathrm{m}^{2}$, and the energy resolution was set to $0.3 \mathrm{eV}$. The intensity of the ratio of the peaks were in the integrated area over the background. The fit-XPS software was used for peak positioning. The Raman measurements were carried out using an imaging spectrometer (iHR550, Horiba Jobin Yvon, Longjumeau cedex, France) in confocal geometry, using $532 \mathrm{~nm}$ laser light for excitation. Notch filter at $\pm 50 \mathrm{~cm}^{-1}$ around $532 \mathrm{~nm}$ was used to filter the scattered light.

The electrodes were prepared by mixing the doped nano iron powder $80 \mathrm{wt}$. \% with high surface area carbon black 5 wt. \% (Ketjenblack EC-300J AkzoNobel), $\mathrm{Bi}_{2} \mathrm{~S}_{3}(5 \mathrm{wt} . \%)$ and PTFE $10 \mathrm{wt} . \%$ (60 wt. \% water suspension). In the other two-electrode formulations, $0.1 \mathrm{wt}$. \% SWCNT (TUBALL ${ }^{\mathrm{TM}}$ SWCNT 0.2 wt. \% in N-Methyl-2-pyrrolidone (NMP) solution) was added. The composite electrode in the form of paste was prepared by mixing the materials as mentioned above with D-70 Shellsol ${ }^{\circledR}$ (Shell Chemicals, Europe) using an agitation rate of 6000 RPM (Waring ${ }^{\circledR}$ laboratory blender LB20ES, Clarkson Laboratory \& Supply Inc., CA, USA). Then, the filtered wet mass was rolled over to a defined thickness of $0.7 \mathrm{~mm}$ on a- nickel wire (100 mesh). The electrode was compressed $\left(375 \mathrm{~kg} \mathrm{~cm}^{-2}\right)$ and dried in $\mathrm{N} 2$ atmosphere and sintered at $325^{\circ} \mathrm{C}$ for $30 \mathrm{~min}[36,37]$. The tested electrodes are specified as shown in Table 1. The amount of iron in the electrodes was found to vary between $22-29 \mathrm{mg} \mathrm{cm}^{-2}$.

Table 1. Electrode details.

\begin{tabular}{|c|c|c|}
\hline Electrode & Sample ID & Fe loading $\left(\mathrm{mg} \mathrm{cm}^{-2}\right)$ \\
\hline 2 wt. $\% \mathrm{Cu}+2$ wt. $\% \mathrm{Sn}$ & CuSn & 29 \\
\hline 2 wt. $\% \mathrm{Cu}+2$ wt. $\% \mathrm{Sn}+0.1$ wt. $\% \mathrm{CNT}$ & CuSnCNT & 27 \\
\hline 2 wt. $\% \mathrm{Cu}+2$ wt. $\% \mathrm{Sn}+0.1$ wt. $\% \mathrm{CNT}+0.65 \mathrm{M}$ of $\mathrm{LiOH}$ & CuSnCNTLi & 27 \\
\hline 4 wt. $\%$ Sn +0.1 wt. $\%$ CNT & SnCNT & 22 \\
\hline
\end{tabular}

The electrodes in Table 1 were studied in a three-electrode cell compartment, in which a conventional sintered nickel electrode $\left(\mathrm{Ni}(\mathrm{OH})_{2} / \mathrm{NiOOH}\right)$ was used as a counter electrode, $\mathrm{Hg} / \mathrm{HgO}$ as a reference electrode and the iron composite as a working electrode. In all the experiment $6 \mathrm{M}$ $\mathrm{KOH}$ was used as electrolyte. In $\mathrm{Li}$ experiment, $6 \mathrm{M} \mathrm{KOH}+0.65 \mathrm{M} \mathrm{LiOH}$ was used as electrolyte. 
All the reported potential values were against $\mathrm{Hg} / \mathrm{HgO}$ reference electrode immersed in the same electrolyte solution.

All the repeated charge (reduction to iron) and discharge (oxidation to iron hydroxide) measurements were done on the Land battery testing system (CT2001-5V2A BTS System). Charge and discharge currents were fixed at 200 and $100 \mathrm{~mA} \mathrm{~g}^{-1}$, respectively, and the discharge potential was limited to $-0.800 \mathrm{~V}$ vs. $\mathrm{Hg} / \mathrm{HgO}$. All the capacity and current details are based on the amount of iron in the composite. Hydrogen evolution and iron reduction potentials were measured at the end of each charging with the initial hump in the charging plateau. Then this was subtracted from the corresponding equilibrium potential value to get the overpotential.

The in operando charge efficiency measurements have been described in earlier work, where electrochemical water splitting catalysis coupled with mass spectrometry allowed the detection of gaseous products [38]. The cell consisted of two chambers and was separated by a nonwoven cellulose membrane (Freudenberg, 700/18F) and sealed with rubber gaskets (Kuntze, ESO2 425-010 EPDM). Each chamber with a volume of $48 \mathrm{~cm}^{2}$ was constantly purged with argon gas through the inlets at the bottom of the chambers. From each chamber the gas outlets were joined in a single exhaust, which served as a gas sampling point for MS measurements (Pfeiffer, Thermostar GSD320-QMG220). The exhaust was then passed through a gas flow meter (Rota Yokogawa, RAK-D41). The iron electrode samples were evaluated with a potentiostat (BioLogic, SP-50) in a two-electrode setup with an oversized conventional nickel electrode as the counter electrode. The geometrical surface areas of the iron and nickel electrodes were 2.25 and $9 \mathrm{~cm}^{2}$, respectively. The electrodes were formed (30-35 cycles) prior to this experiment. All samples for in operando charge efficiencies were cycled three times with 5,10 and $15 \mathrm{~mA} \mathrm{~cm}^{-2}$ of charge and $5 \mathrm{~mA} \mathrm{~cm} \mathrm{~cm}^{-2}$ for discharge.

\section{Results and Discussion}

\subsection{Material Characterizations}

Figure 1 illustrates the crystal phases for the XRD patterns of the two samples: CuSn (a) and $\mathrm{Sn}(\mathrm{b})$. In both samples, $\alpha$-Fe was the dominant phase. In the case of the $\mathrm{Sn}$ sample, $\mathrm{Fe}_{3} \mathrm{SnC}$ was also observed as a minor phase along with the $\alpha$-Fe phase. However, when 2 wt. \% Cu was introduced with 2 wt. \% Sn, $\mathrm{Fe}_{3} \mathrm{Sn}$ phases were observed with traces of $\mathrm{Fe}_{3} \mathrm{SnC}$. Metallic $\mathrm{Cu}$ and $\mathrm{Sn}$ phases were not detected due to the low concentrations of the respective elements. Even though both samples have more than $20 \mathrm{wt}$. \% carbon, no graphitic phases are observed, which suggest that these carbons are of amorphous in nature, which may improve the electrode conductivity, whereas the porous network will also increase the ionic conductivity $[39,40]$. A further advantage of the carbon is that it will buffer the volume expansion and maintain stable electrical conductivity of the iron electrode during the electrochemical cycling [41].

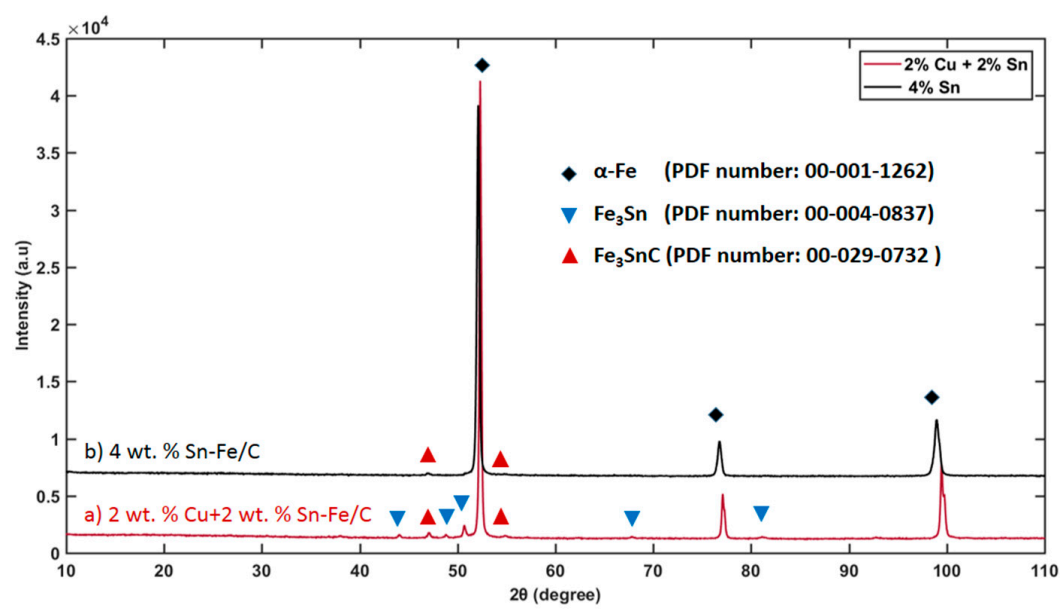

Figure 1. XRD patterns of the (a) CuSn and (b) Sn samples. 
Figure 2a,b,d,e shows the SEM micrographs of CuSn- (Figure 2a-c) and Sn- (Figure 2d-f) doped nano iron. As seen from Figure 2, both the samples possess rough spherical structure $(5-10 \mu \mathrm{m})$ with an internal cavity. Closer inspection of the CuSn-doped sample, (Figure 2b) reveals the existence of smaller spherical particles $(250-450 \mathrm{~nm})$ fused together to form a continuous network which enhances the interparticle connectivity. Meanwhile, the Sn-doped sample (Figure 2e) showed irregular shapes viz. rectangular, acicular, and spherical. Figure $2 \mathrm{c}, \mathrm{f}$ shows the elemental distribution of the CuSnand Sn-doped samples. In both samples, Fe, Sn, O, and C were uniformly distributed. For the former sample, $\mathrm{Cu}$ was evenly distributed with Fe. Interestingly, $\mathrm{O}$ and $\mathrm{C}$ observed in the elemental mapping were not detected as any phases by the XRD analyses; however, Figure $2 c, f$ display surface enrichment and distribution. Uniform distribution of $\mathrm{Cu}, \mathrm{Sn}$, and $\mathrm{C}$ in the electrode enhance the electronic conductivity by maintaining a continuous conductive matrix, which could be beneficial for stable iron electrode operation.

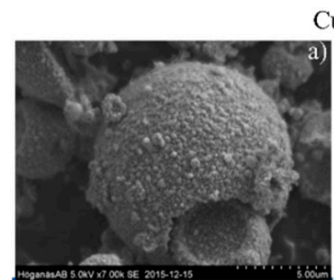

CuSn
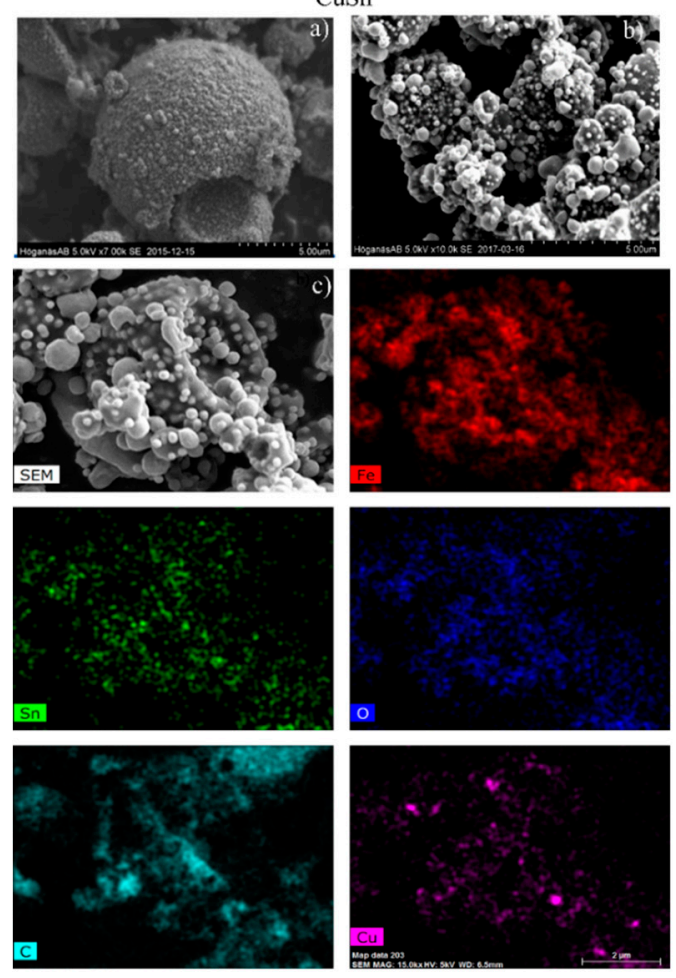

$\mathrm{Sn}$
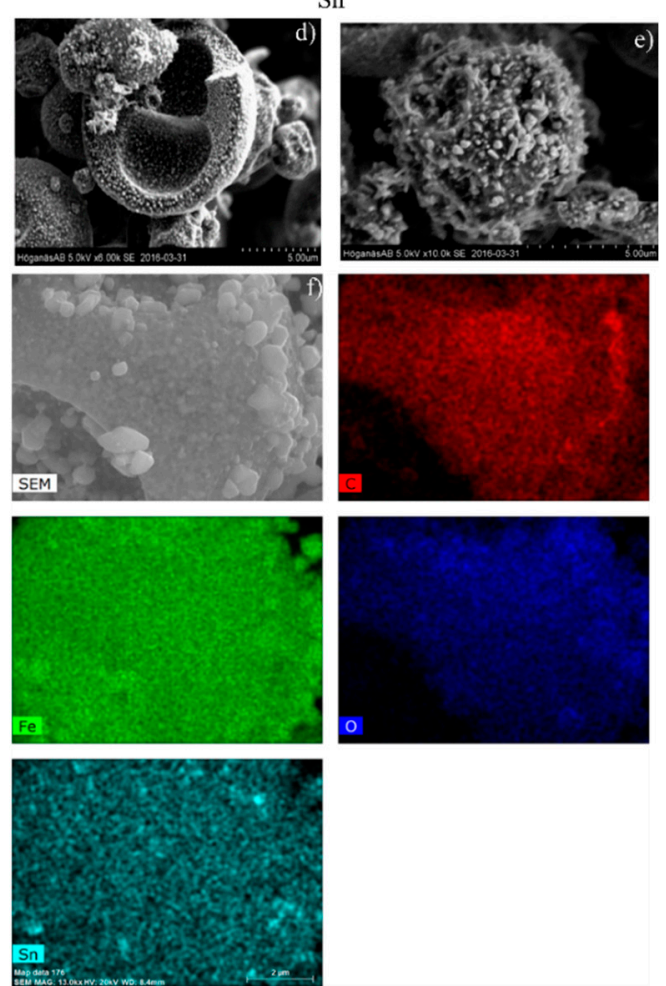

Figure 2. SEM and elemental mapping for samples of CuSn $(\mathbf{a}-\mathbf{c})$ and $\mathrm{Sn}(\mathbf{d}-\mathbf{f})$.

Moreover, both samples were analyzed by TEM with the results as shown in Figure 3. Figure 3a presents the morphology of the CuSn sample showing uniform particle sizes (100-300 nm) embedded in the filamentous carbon layer. In the Sn sample shown in Figure $3 b$, the particles are smaller (30-150 nm), unevenly sized with irregular shapes. From the TEM mass contrast, darker and lighter platelets shaped iron particle are observed. Thus, closely fused interconnected particles tend to decrease the electrode resistance and enhance the electrochemical performance of the CuSn sample [42].

Figure 4 displays the XPS spectra of the CuSn sample. Figure 4 a shows the Fe $2 p$ spectrum with characteristic peaks at $706.7 \mathrm{eV}$ of metallic Fe(0) $2 \mathrm{p}_{2 / 3}, 711 \mathrm{eV}$ of Fe(II) $2 \mathrm{p}_{2 / 3}$ and $724.5 \mathrm{eV} 2 \mathrm{p}_{1 / 2}$. Figure $4 \mathrm{~b}$ shows the $\mathrm{Cu} 2 \mathrm{p}$ spectrum, with peaks observed at 932.6 and $933.6 \mathrm{eV}$ corresponding to metallic $\mathrm{Cu}(0), \mathrm{Cu}(\mathrm{I})$ and $\mathrm{Cu}(\mathrm{II})$. The $\mathrm{Sn} 3 \mathrm{~d}_{2 / 5}$ spectrum (Figure 4c) has one sharp peak at $486.9 \mathrm{eV}$. This peak corresponds to $\mathrm{SnO}$ or $\mathrm{SnO}_{2}$. Moreover, a weak shoulder is observed at $485 \mathrm{eV}$ for metallic $\mathrm{Sn}(0)$. Figure $4 \mathrm{~d}$ illustrates the $\mathrm{O} 1 \mathrm{~s}$ spectrum. There are two peaks: one at ca $530 \mathrm{eV}$ corresponding to the metal oxides $\mathrm{Fe}_{2} \mathrm{O}_{3}, \mathrm{Fe}_{3} \mathrm{O}_{4}, \mathrm{FeO}$ and $\mathrm{SnO}_{2}$, and the second peak at 532.6 eV related to $\mathrm{OH}$ [43]. The C 1 s spectrum (Figure $4 \mathrm{e}$ ) shows one strong peak at $284.8 \mathrm{eV}$ confirming the presence of carbon 
in the sample. The XPS results further confirm that the copper, iron, and tin species exist either in metallic or oxide form on the sample surface. The intensity ratios with corrected atomic sensitivity factor (ASF) (excluding C) are presented in Table 2. We have set the $\mathrm{Cu}$ intensity to 1 . The intensity ratio corroborates that the tin species are enriched, and copper is depleted on the surface. Almost all iron at the surface is oxidized in the form of $\mathrm{Fe}_{2} \mathrm{O}_{3}$ and $\mathrm{Fe}_{3} \mathrm{O}_{4}$, while the core is maintained in metallic form. There is a weak signal from $\mathrm{Fe}_{3} \mathrm{SnC}$ in the $\mathrm{XRD}$ data. Given the rather small relative amount we can neither confirm nor exclude carbide from our XPS-data.
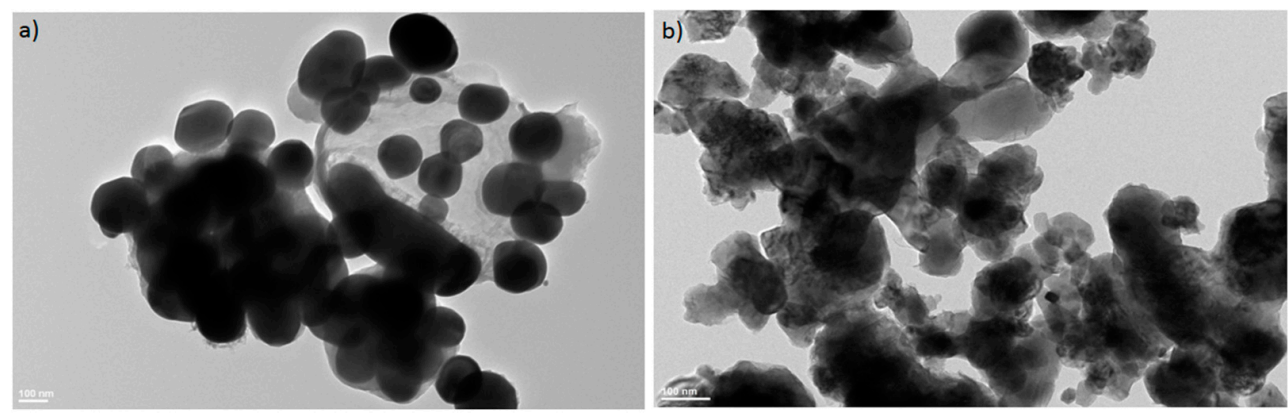

Figure 3. TEM images of CuSn (a) and Sn (b).
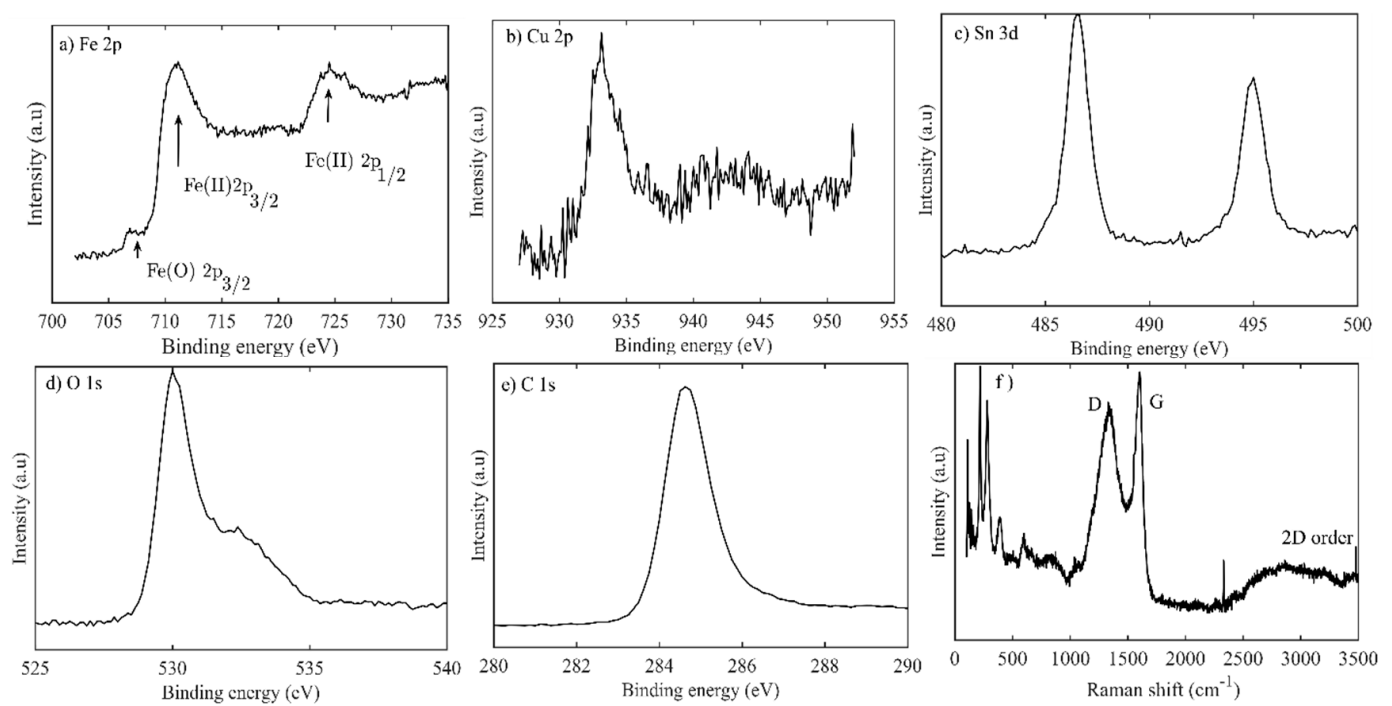

Figure 4. (a-e) XPS spectra and (f) Raman spectrum for the CuSn sample.

Table 2. XPS intensity ratio.

\begin{tabular}{cc}
\hline Element & ASF Corrected XPS Peak Intensity \\
\hline Fe & 40 \\
Cu & 1 \\
O & 95 \\
Sn & 20 \\
\hline
\end{tabular}

To discern the type of carbon in the CuSn sample, Raman spectroscopy was carried out as shown in Figure 4f. Several prominent peaks are observed at 216, 277, 401, 1340, $1607 \mathrm{~cm}^{-1}$. The first three of these peaks correspond to $\mathrm{Fe}_{2} \mathrm{O}_{3}$ [44], while the remaining two peaks represent the $\mathrm{D}$ and $\mathrm{G}$ bands in carbon materials. Moreover, another diffuse band around $2700 \mathrm{~cm}^{-1}$ is characteristic for the 2D band. Both the D and $G$ bands originate from the in-plane optical phonons in the graphene layer [45]. The D band is not observed in defect-free Highly Ordered Pyrolytic Graphite (HOPG), but becomes Raman active due to defects within the graphene planes [45]. The deconvoluted intensity ratio $\left(\mathrm{I}_{\mathrm{D}} / \mathrm{I}_{\mathrm{G}}\right)$ of the $\mathrm{D}$ and $\mathrm{G}$ bands gives the degree of graphitization in the sample and an $\mathrm{I}_{\mathrm{D}} / \mathrm{I}_{\mathrm{G}}$ value of 0.64 was 
obtained. This $\left(\mathrm{I}_{\mathrm{D}} / \mathrm{I}_{\mathrm{G}}\right)$ ratio and the weak and broad $2 \mathrm{D}$ band suggest that the sample is conductive and partially graphitized [46]. The Raman results confirm that amorphous carbon is present in the $\mathrm{CuSn}$ sample. Furthermore, the presence of $\mathrm{FeO}_{\mathrm{X}}$ peak suggests that carbon layer does not completely coated over the particles.

\subsection{Electrochemical Performance of the Electrodes}

Figure 5 illustrates the discharge profiles of the electrodes at the constant current discharge of $100 \mathrm{~mA} \mathrm{~g}^{-1}$. All four samples had 5 wt. \% Bi $\mathrm{B}_{3}, 10$ wt. \% PTFE and 5 wt. \% Ketjenblack EC-300J. Two of the samples had 0.1 wt. \% SWCNT (TUBALL ${ }^{\mathrm{TM}}$ OCSIAL EUROPE, Leudelange, Grand-Duché de Luxembourg). Their initial discharge capacities are shown in Table 3. Among them, sample CuSn with 0.1 wt. \% CNT and $0.65 \mathrm{M} \mathrm{LiOH}$ demonstrate the highest initial discharge capacity at $603 \mathrm{mAh} \mathrm{g}^{-1}$ with $91 \%$ charge efficiency, while the CuSn sample with CNT and without CNT exhibit 470 and $434 \mathrm{mAh} \mathrm{g}^{-1}$ with 93 and $82 \%$ charge efficiency, respectively. This performance increase is due to the enhanced electrode conductivity and porosity created by $\mathrm{CNT}, \mathrm{Cu}$, amorphous carbon network, which acts as an electron transport and ion transport pathways. Thus, provides a better interface and the ideal reaction site for charging reaction $[47,48]$. While the addition of $\mathrm{LiOH}$ increase the iron dissolution and form a porous hydroxide, which enhancing the electrolyte access to the active material [29]. In contrast to CuSn containing samples, the Sn sample with CNT shows low discharge capacity of $378 \mathrm{mAh} \mathrm{g}^{-1}$ and $76.7 \%$ efficiency, which indicates that 4 wt. \% Sn only could not improve the electrochemical performance as with the CuSn sample. Further observations of discharge plateaus (Figure 5) show that all the electrodes have an initial stable discharge plateau at $-0.93 \mathrm{~V}$ and when the cycle number increases the discharge plateau potentials decrease to $-0.9 \mathrm{~V}$. This potential decay implies that the electrode resistance is increased during cycling, caused by accumulated non-conducting discharge products preventing further oxidation of iron. This effect is more significant on the SnCNT sample, which showed lower performance with the highest overpotential and capacity decay among the four electrodes. In our previous study, $2 \% \mathrm{Cu}$ doped iron had delivered stable performance at $367 \mathrm{mAh} \mathrm{g}^{-1}$ of discharge capacity and with $80 \%$ of charge efficiency [34]. Comparing the bare $\mathrm{Cu}$ and bare Sn-doped samples, Sn performance shows poor performance in terms of capacity and cyclability. Possible reasons for this decay could be tin's lower conductivity without the presence of $\mathrm{Cu}$ and non-uniform nanoparticle size distribution as shown in Figures $2 \mathrm{~d}$ and $3 \mathrm{~b}$.

The charge profiles of the electrodes at $200 \mathrm{~mA} \mathrm{~g}^{-1}$ are given in Figure 6. The iron hydroxide reduction voltage plateaus appear between $-1.1 \mathrm{~V}$ to $-1.15 \mathrm{~V}$. During the initial cycles all the electrodes have a single charge plateau and after increasing cycle number two distinct plateaus are observed, one for the iron reduction and another for the hydrogen evolution at $-1.2 \mathrm{~V}$. The length of these two plateaus varies with cycle numbers. It can be seen from the CNT containing CuSn electrodes that the iron reduction potential is much lower (about $10 \mathrm{mV}$ ) than the CuSn sample without CNT. This confirmed that the charge efficiency is improved by the addition of $0.1 \mathrm{wt}$. \% CNT in the CuSn electrode [21]. The other noticeable difference among the electrodes is the potential overshoot at the start of the charging (inset Figure 6). This primarily arises due to the resistance of iron hydroxide nucleation to Fe transformation [11]. In the CNT containing electrodes this overshoot gradually disappeared over cycles. Increase in the overshoot potential was observed for the CuSn as well indicating that the CNT addition favored nucleation. Two overshoot regions are observed with the $\mathrm{Sn}$ sample. This could be due to dissolved tin being reduced back to form Sn or Fe-Sn alloys [35,49].

Table 3. Performance characteristics of the electrodes.

\begin{tabular}{ccc}
\hline Electrode & Initial Discharge Capacity $\left(\mathbf{m A h ~} \mathbf{g}^{-\mathbf{1}}\right)$ & Initial Charge Efficiency (\%) \\
\hline CuSn & 434 & 82.6 \\
CuSnCNT & 470 & 93.0 \\
CuSnCNTLi & 603 & 91.3 \\
SnCNT & 378 & 76.7 \\
\hline
\end{tabular}



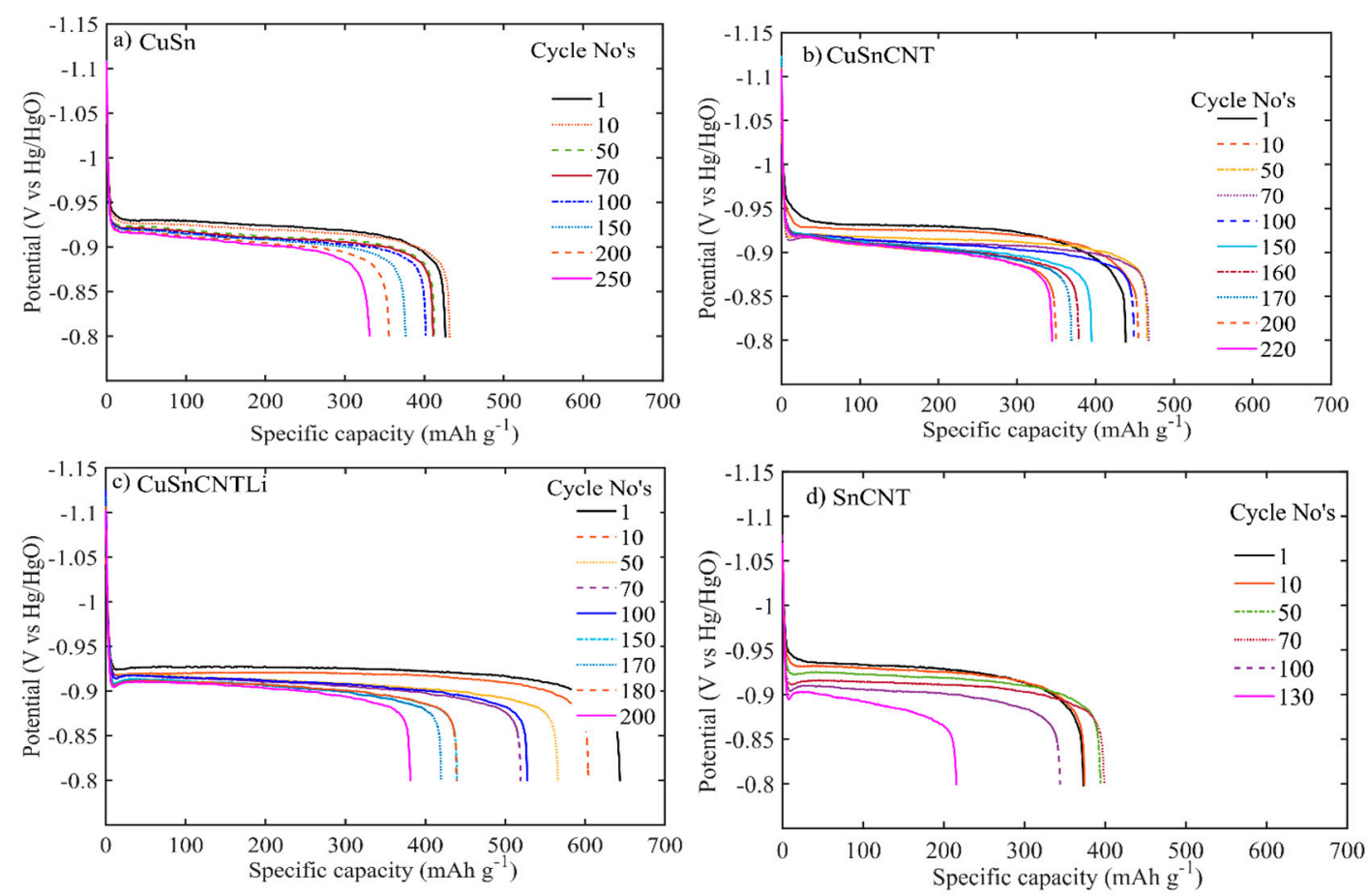

Figure 5. Specific discharge profiles of electrodes at current density of $100 \mathrm{~mA} \mathrm{~g}^{-1}$.
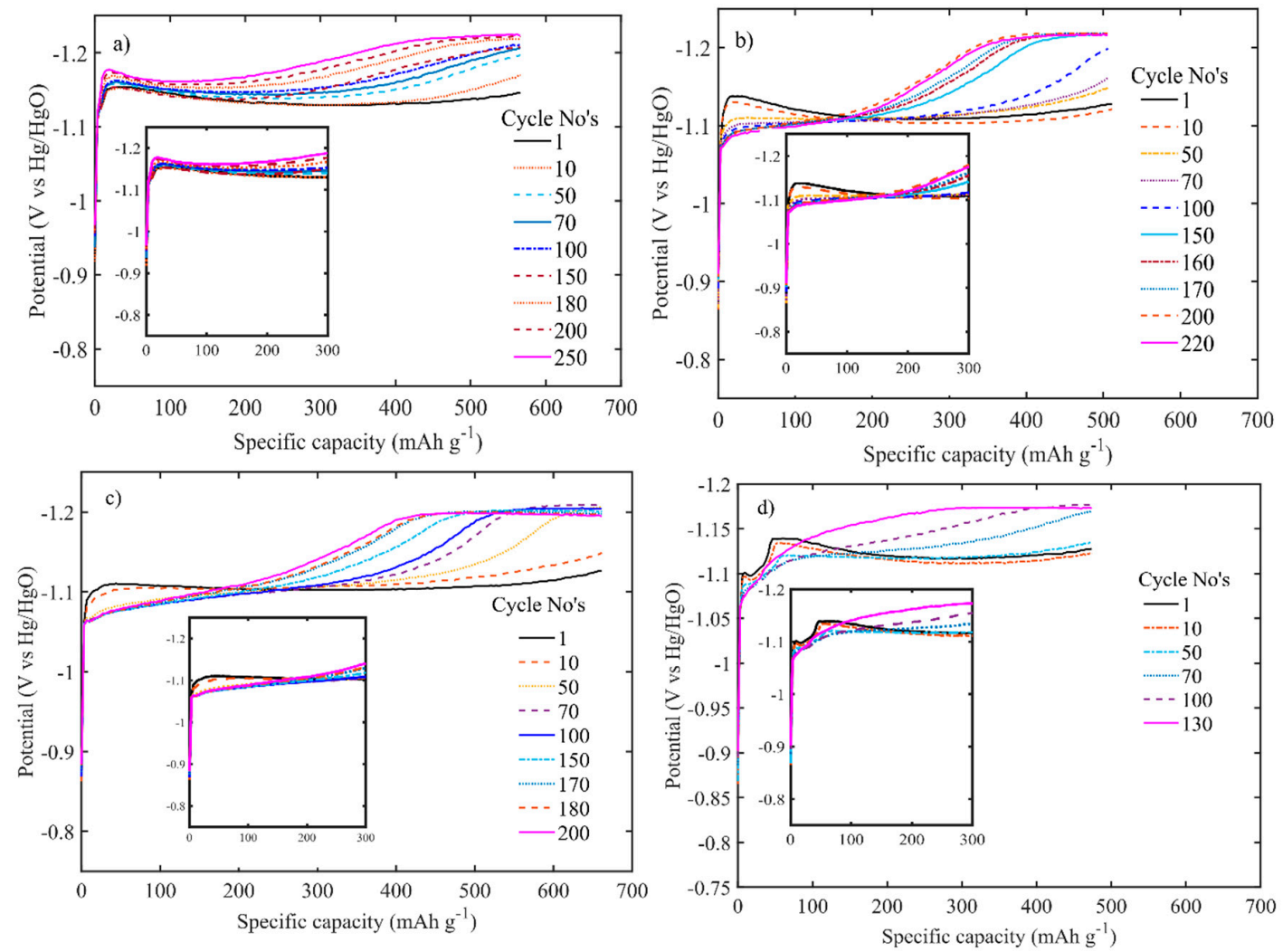

Figure 6. Specific charge profiles of electrodes at current density of $200 \mathrm{~mA} \mathrm{~g}^{-1}$. (inset figure-Potential overshoot along the cycles). (a) CuSn; (b) CuSnCNT; (c) CuSnCNTLi; (d) SnCNT.

Figure 7 shows the overpotential trends of iron reduction and hydrogen evolution during cycling. The first plateau corresponds to iron reduction as shown in Figure $7 \mathrm{a}$, and the second plateau to hydrogen evolution as shown in Figure $7 \mathrm{~b}$. Long iron reduction plateau and a low overpotential results in a higher charge acceptance. The iron reduction overpotential is more positive for the CNT electrodes 
compared to the CuSn electrode. Without CNT addition the iron reduction overpotential is found to be around $-0.17 \mathrm{~V}$ while with CNT, the overpotential was reduced to $-0.14 \mathrm{~V}$, while the overpotential dropped additionally with $\mathrm{LiOH}$ to $-0.11 \mathrm{~V}$. On the contrary, the $4 \mathrm{wt}$. \% Sn shows an increasing overpotential (Figure 6d) despite the addition of CNT. Thus, CNT and $\mathrm{LiOH}$ addition decrease the iron reduction overpotential only in the CuSn sample. The hydrogen evolution region takes place at lower overpotentials during the initial cycles and increases over subsequent cycles. However, this overpotential increment does not translate into improved performance. Upon the charge/discharge cycles, the iron reduction plateau length gradually decreases while the hydrogen evolution plateau slowly increases to higher potentials. This could be ascribed to the depletion of sulfur and subsequent Bi enrichment on the iron electrode [20,34].
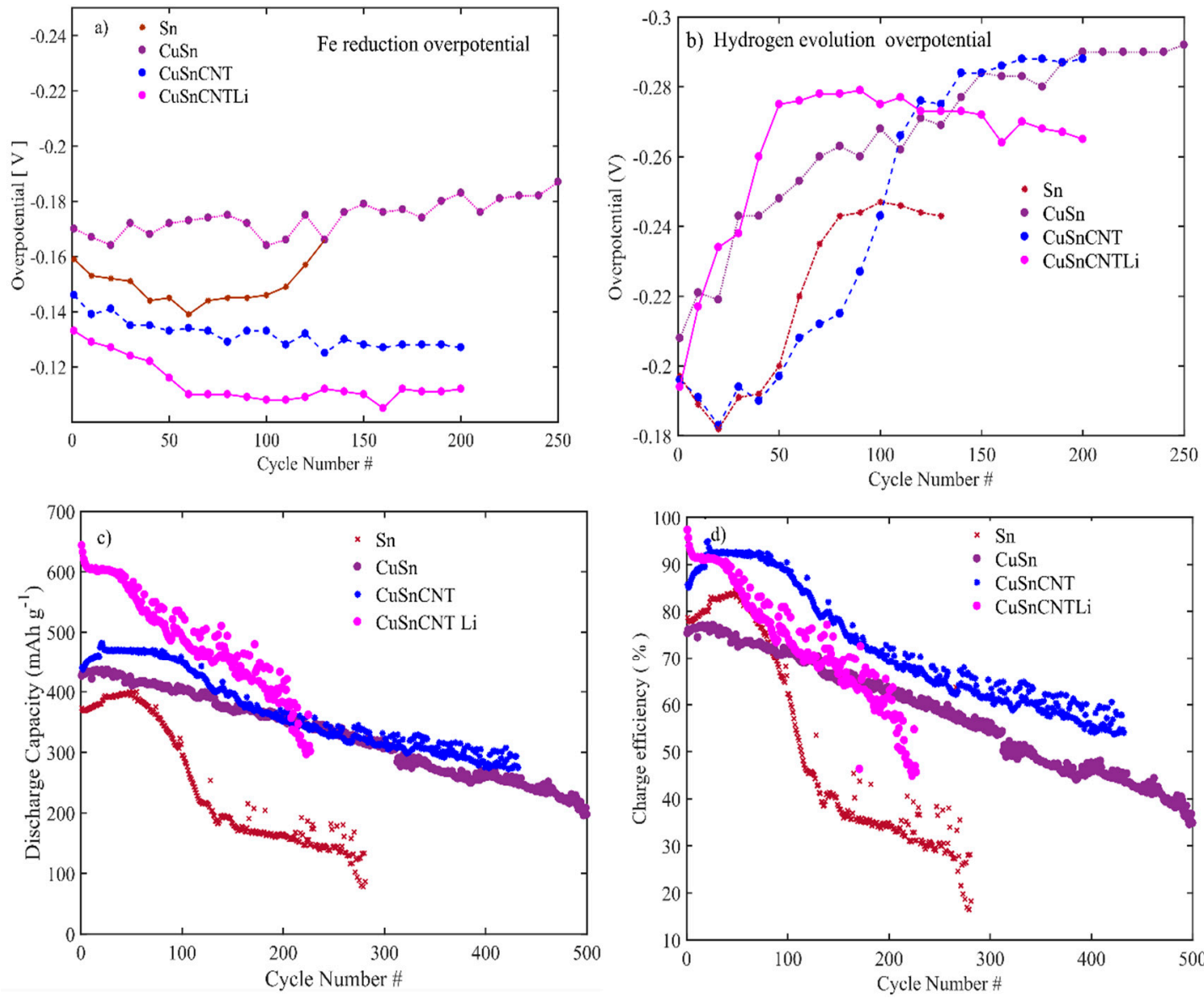

Figure 7. Change in overpotential over cycles (a) Fe reduction overpotential (first plateau); (b) hydrogen evolution overpotential (second plateau); (c) Specific discharge capacity and (d) Charge efficiency of electrodes vs. cycle number.

Figure $7 \mathrm{c}, \mathrm{d}$ illustrates the life cycle assessment of the electrodes at a constant current charge of $200 \mathrm{~mA} \mathrm{~g}^{-1}$ and discharge of $100 \mathrm{~mA} \mathrm{~g}^{-1}$. The capacity of the CuSnCNTLi electrode drops to $50 \%$ from 600 (at 1st cycle) to $300 \mathrm{mAh} \mathrm{g}^{-1}$ at 225th cycle (loss of $1.3 \mathrm{mAh} \mathrm{g}^{-1} /$ cycle). The CuSnCNT electrode is more stable with a capacity of $277 \mathrm{mAh} \mathrm{g}^{-1}$ with an $55 \%$ charge efficiency after 450 cycles (loss of $0.41 \mathrm{mAh} \mathrm{g}^{-1}$ /cycle). At 450 cycles, the capacity of the CuSn sample drops (loss of $0.47 \mathrm{mAh} \mathrm{g}^{-1}$ /cycle) to $250 \mathrm{mAh} \mathrm{g}^{-1}$ with an efficiency of $45 \%$. Even though LiOH addition remarkably increases the capacity up to $62 \%$ of its theoretical value; its long-term stability is found to be poor. The prolonged cycling increases the $\mathrm{H}_{2}$ evolution and the mechanical stability of the electrode worsens because of too high porosity resulting in loss of active material from the electrode [29]. Similarly, the SnCNT (loss of $0.96 \mathrm{mAh} \mathrm{g}^{-1} /$ cycle) sample also presents poor long-term stability. 
As shown in the TEM images in Figure 3, the large particle size distribution and excessive $\mathrm{H}_{2}$ evolution is detrimental to the long cycle performance of the electrode. The high capacities could be realized by using the nano CuSn sample with different additives ( $\mathrm{LiOH}$ and $\mathrm{CNT}$ ), which also imply that the CNT addition increases the porosity. The porosities of the electrodes lied in between 55 to $60 \%$. Highly porous electrodes have higher interparticle resistance, compared to a metallic conductor. During cycling, increase in the interparticle contact resistance affects the charge acceptance of the iron reduction and consequently accelerates the capacity decay.

Differential electrochemical mass spectrometry is a useful technique to study the aging of batteries by coupling mass spectrometry with electrochemical techniques [50]. Here, in operando charge efficiency studies were performed when charging the iron electrodes at different current densities and simultaneously quantifying the amount of $\mathrm{H}_{2}$ gas collected in the mass spectrometer. In this study, it was assumed that deviation from $100 \%$ charge efficiency is solely caused by $\mathrm{H}_{2}$ gas evolution originating from charging the iron electrodes. The measurements are based on Faraday's law:

$$
\mathrm{n}=\frac{\mathrm{It}}{\mathrm{zF}}
$$

where $\mathrm{n}=$ number of moles $(\mathrm{mol}), \mathrm{I}=$ current $(\mathrm{A}), \mathrm{t}=$ time $(\mathrm{s}), \mathrm{z}=$ electrons transferred per ion $\left(\mathrm{z}=2\right.$ for $\mathrm{H}_{2}$ ) and $\mathrm{F}=96,485 \mathrm{C} \mathrm{mol}^{-1}$. Stainless steel (SS) was chosen as a standard to quantify the accumulated $\mathrm{H}_{2}$ gas upon assuming $100 \%$ efficiency. A linear potential sweep from 0.3 to $0.55 \mathrm{~V}$ vs. $\mathrm{Ag} / \mathrm{AgCl}$ with a sweeping rate of $0.2 \mathrm{mV} \mathrm{s}^{-1}$ was done to calibrate the accumulated $\mathrm{H}_{2}$ gas on SS and the charge passed was correlated with the recorded counts of $\mathrm{H}_{2}$ from the mass spectrometer. Calibration was done prior to each sample study and quantification factors were calculated according to:

$$
\text { quant. factor }=\frac{\int \mathrm{I}_{\mathrm{EC}} \mathrm{t}}{\int \mathrm{I}_{\mathrm{MS}} \mathrm{t}}
$$

where $\mathrm{I}_{\mathrm{EC}}=$ current recorded from the potentiostat $(\mathrm{A})$ and $\mathrm{I}_{\mathrm{MS}}=$ extracted ion signal from the MS $(\mathrm{A})$. The quantification factors were determined to $(12.18 \pm 1.32) \times 10^{6}$. The number of $\mathrm{H}_{2}(g)$ moles per second evolved during charge of the iron electrodes was calculated by:

$$
\frac{\mathrm{n}_{\mathrm{H}_{2}(g)}}{\mathrm{t}}=\text { quant. factor } \cdot \frac{\mathrm{I}_{\mathrm{MS}}}{\mathrm{zF}}
$$

where $\mathrm{n}_{\mathrm{H}_{2}(g)}=$ number of $\mathrm{H}_{2}(g)$ moles evolved (mol). This is further derived to the cumulative $\mathrm{H}_{2}(g)$ capacity:

$$
\mathrm{Q}_{\mathrm{H}_{2}(g)}=\text { quant. factor } \cdot \mathrm{I}_{\mathrm{MS}} \mathrm{t}
$$

where $\mathrm{Q}_{\mathrm{H}_{2}(g)}=$ charge passed corresponding to $\mathrm{H}_{2}(g)(\mathrm{C})$. Lastly, the charge efficiency was defined as:

$$
\eta_{\text {charge }}=\frac{Q_{\text {tot }}-Q_{\mathrm{H}_{2}(g)}}{Q_{\text {tot }}}
$$

where $Q_{\text {tot }}=$ total capacity of the iron electrode obtained from the potentiostat.

In Figure 8 the charge efficiency at 5, 10 and $15 \mathrm{~mA} \mathrm{~cm}^{-2}$ is shown for the four samples. For each sample, the top plot shows the cell potential and number of $\mathrm{H}_{2}(g)$ moles (Equation (6)) vs. time while the bottom plot shows the charge efficiency (Equation (8)) and cumulative $\mathrm{H}_{2}(g)$ capacity (Equation (7)) vs. time. Each charge curve was taken at the last cycle of the specific current density. Also, the $\mathrm{H}_{2}(g)$ counts from the MS was extended to ensure that all accumulated gas in the system was considered. The highest efficiencies achieved were in the following order: CuSnCNT > CuSn $>$ CuSnCNTLi $>$ SnCNT. These results are comparable to Table 3, except that the order between CuSn and CuSnCNTLi are on the opposite. The lower efficiency obtained for CuSnCNTLi is due to the prolonged charging at potentials above $1.65 \mathrm{~V}$, evident from Figure 8c. The efficiency evolution during charge in Figure 8 shows three distinguished slopes at potentials: (1) below 1.5 V, (2) between 1.5-1.6 V and (3) above 
1.6 V. In the first region, the least $\mathrm{H}_{2}(g)$ amount was evolved while nucleation of $\mathrm{Fe}(\mathrm{OH})_{2}$ to $\mathrm{Fe}$ took place. In the second, constant rate of $\mathrm{H}_{2}(g)$ was released upon iron reduction. Lastly, $\mathrm{H}_{2}(g)$ evolution dominated above $1.6 \mathrm{~V}$ and led to the overcharging the iron electrode. The highest efficiency of charging iron electrodes occurred at higher current densities, and the efficiency results showed that the electrodes benefited from charging at higher current densities than $10 \mathrm{~mA} \mathrm{~cm}{ }^{-2}$. Samples with enhanced conductivity, for instance added $\mathrm{Cu}$ and $\mathrm{CNT}$, revealed higher charge acceptance of iron reduction, which ultimately suppressed the $\mathrm{H}_{2}(g)$ evolution. The efficiencies acquired from the mass spectrometer were compared with the coulombic efficiencies from the potentiostat and are validated with the results as shown in Table 4 with small deviations as a result.
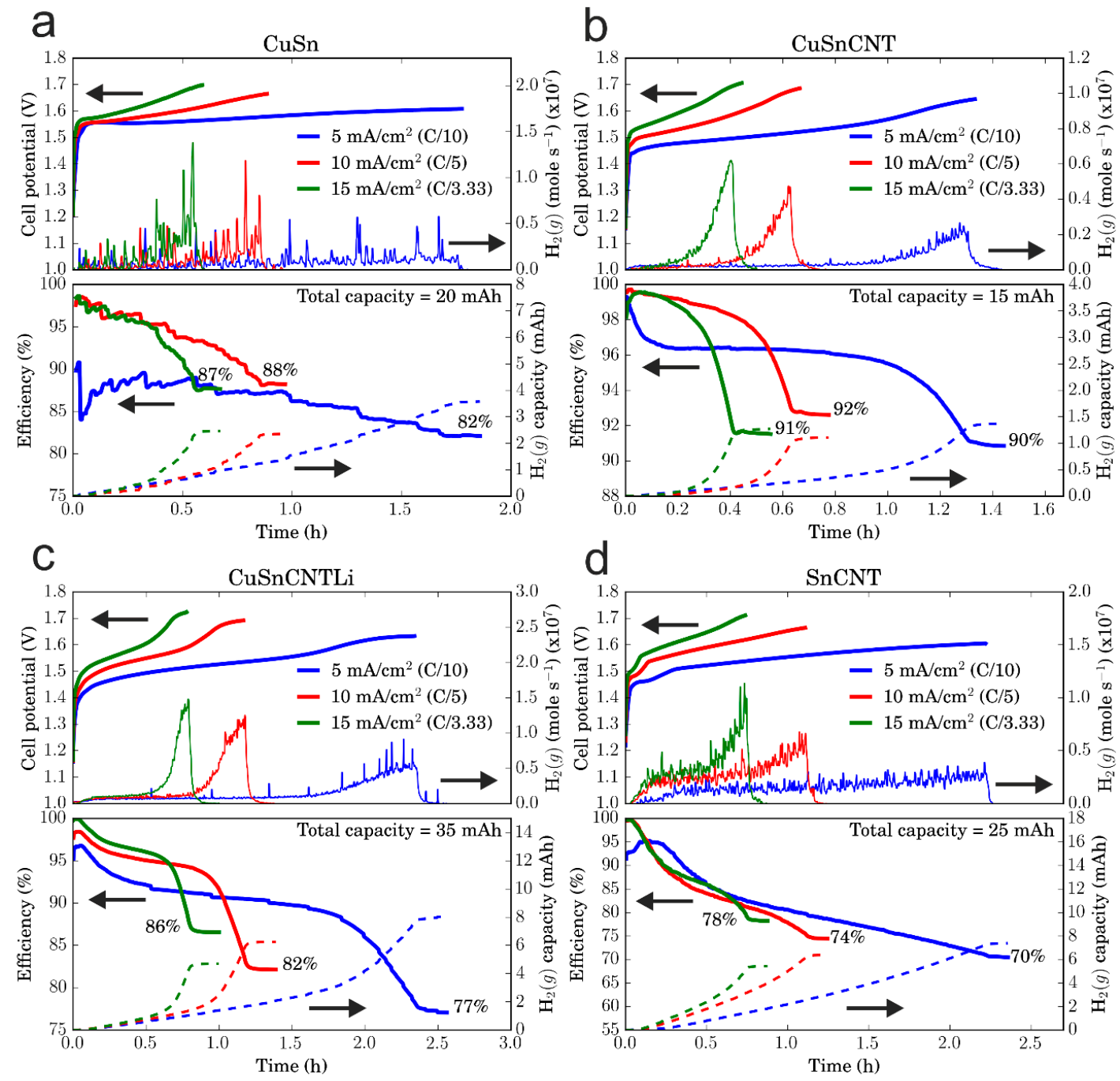

Figure 8. Charge efficiency measurements at 5, 10 and $15 \mathrm{~mA} \mathrm{~cm}^{-2}$ of CuSn (a), CuSnCNT (b), CuSnCNTLi (c) and SnCNT (d).

Table 4. Efficiency comparison.

\begin{tabular}{|c|c|c|}
\hline Sample & ${ }^{a} \eta_{\text {charge }}\left(5 / 10 / 15 \mathrm{~mA} \mathrm{~cm}^{-2}\right)$ & ${ }^{b} \eta_{C E}\left(5 / 10 / 15 \mathrm{~mA} \mathrm{~cm}^{-2}\right)$ \\
\hline $\mathrm{CuSn}$ & $82 / 88 / 87 \%$ & $81 / 88 / 88 \%$ \\
\hline CuSnCNT & $90 / 92 / 91 \%$ & $93 / 92 / 90 \%$ \\
\hline CuSnCNTLi & $77 / 82 / 86 \%$ & $77 / 83 / 88 \%$ \\
\hline SnCNT & $70 / 74 / 78 \%$ & $70 / 76 / 80 \%$ \\
\hline
\end{tabular}

\footnotetext{
${ }^{\mathrm{a}} \eta_{\text {charge }}=\frac{\mathrm{Q}_{\text {tot }}-\mathrm{Q}_{\mathrm{H}_{2}(g)}}{\mathrm{Q}_{\text {tot }}}$ (note: charge efficiency based on the difference between total and $\mathrm{H}_{2}(g)$ capacity); ${ }^{\mathrm{b}} \eta_{\mathrm{CE}}=$ $\frac{Q_{\text {discharge }}}{Q_{\text {charge }}}$ (note: coulombic efficiency calculated from the potentiostat software).
} 
In summary, we have studied two type of nano iron doped electrode materials: one with CuSn and the other one with Sn. Among them, CuSn-doped nano iron samples have delivered high capacities and efficiencies ranging from 434 to $603 \mathrm{mAh} \mathrm{g}^{-1}$ and 83 to $93 \%$, respectively, depending on the additives (CNT, or CNT and $\mathrm{LiOH}$ ). These performance values are even higher from the reported values in literature $[18,23,34]$. Based on coupled mass spectrometry and charging iron electrodes, and the galvanostatic cycling profile, CNT containing electrodes have a stable hydrogen evolution plateaus at $1.65 \mathrm{~V}$ vs. $\mathrm{NiOOH}$ or $-1.2 \mathrm{~V}$ vs. $\mathrm{Hg} / \mathrm{HgO}$. This high rate of hydrogen evolution is not beneficial to the electrode structure. It might destroy the electrode pore structure and interconnectivity of the particles. On the contrary to this, the CuSn does not have pronounced hydrogen evolution plateaus. In the meanwhile, the hydrogen evolution is continuing throughout the charging, not limited to the end charge. MS data (Figure 8a) also confirms this trend. Therefore, inhibiting the high hydrogen evolution could improve the electrode mechanical stability and life cycle, which could be done by constant voltage charging or potential limited constant current charging. High current charging (10 and $15 \mathrm{~mA} \mathrm{~cm}^{-2}$ ) improved the electrode efficiency as shown in Table 4 .

This study shows that addition of both CUSn, partly amorphous carbon and CNT improve the electrode performance. The $\mathrm{Cu}$, carbon and $\mathrm{CNT}$ give a stable interfacial conductivity irrespective of the state of charge. Furthermore, Sn could slow down the hydrogen evolution kinetics [35]. These dopant elements and CNT additive enhance the nano iron cyclability.

\section{Conclusions}

In our study, CuSn and Sn-doped Nano iron/carbon composites were investigated as negative electrode material for alkaline electrolyte. The best performing CuSn electrode has shown interconnected iron particles, uniformly distributed $\mathrm{Cu}, \mathrm{Sn}$ and carbon network for effective charge and discharge operation. As a result, of this, CuSn-based electrodes have shown excellent performance. This work also demonstrates the effectiveness of SWCNT and $\mathrm{LiOH}$ addition to the electrode on the performance. The CNT addition improves the charge efficiency and capacity to $93 \%$ and $470 \mathrm{mAh} \mathrm{g}^{-1}$, respectively. Even though the CNT with $\mathrm{LiOH}$ addition increased the performance to $91 \%$ and $603 \mathrm{mAh} \mathrm{g}^{-1}$, its cycle stability is compromised. In operando MS analysis quantifies the amount of evolved hydrogen and shows the three different hydrogen evolution rate domains. The higher hydrogen evolution at the end of the charge made the electrodes begin to fail rapidly. The different charge current density vs. performance shows that at higher current density the amount of evolved hydrogen is reduced, and the performance is also improved dramatically. These findings will help to develop suitable charging programs for the iron electrodes. This CuSn nano iron is a suitable negative electrode for the alkaline $\mathrm{Ni}$-Fe or Fe-air battery application.

Author Contributions: A.R.P. and Y.K. conceived and designed the experiments; A.R.P. performed all battery cycling experiments; H.S. designed the GC-MS set-up; M.C. ran the GC-MS of the cell, analyzed and wrote that part. Y.K.; M.G.; D.N.; B.S.; H.V. supervised both A.R.P. and M.C. and were part of the discussion. M.G. and M.B.J. ran the XPS and analyzed that data. A.R.P. wrote the article.

Funding: This work is supported by the Swedish Energy Agency with the project number: 39078-1.

Acknowledgments: This work is supported by the Swedish Energy Agency.

Conflicts of Interest: The authors declare no conflict of interest.

\section{References}

1. Matthews, H.D.; Kirsten, Z.; Reto, K.; Myles, R.A. Focus on cumulative emissions, global carbon budgets and the implications for climate mitigation targets. Environ. Res. Lett. 2018, 13, 010201. [CrossRef]

2. Larcher, D.; Tarascon, J.M. Towards greener and more sustainable batteries for electrical energy storage. Nat. Chem. 2015, 7, 19-29. [CrossRef] [PubMed]

3. Ravikumar, M.K.; Rathod, S.; Jaiswal, N.; Patil, S.; Shukla, A. The renaissance in redox flow batteries. J. Solid State Electrochem. 2016, 1-22. [CrossRef] 
4. Akinyele, D.O.; Rayudu, R.K. Review of energy storage technologies for sustainable power networks. Sustain. Energy Technol. Assess. 2014, 8, 74-91. [CrossRef]

5. U.S. Department of Energy. Grid Energy Storage Report. 2013.

6. Öjefors, L.; Carlsson, L. An iron-Air vehicle battery. J. Power Sources 1978, 2, 287-296. [CrossRef]

7. Narayanan, S.R.; Prakash, G.K.S.; Manohar, A.; Yang, B.; Malkhandi, S.; Kindler, A. Materials challenges and technical approaches for realizing inexpensive and robust iron-air batteries for large-scale energy storage. Solid State Ion. 2012, 216, 105-109. [CrossRef]

8. Öjefors, L. Self-discharge of the alkaline iron electrode. Electrochim. Acta 1976, 21, 263-266. [CrossRef]

9. Wang, H.; Liang, Y.; Gong, M.; Li, Y.; Chang, W.; Mefford, T.; Zhou, J.; Wang, J.; Regier, T.; Wei, F.; et al. An ultrafast nickel-iron battery from strongly coupled inorganic nanoparticle/nanocarbon hybrid materials. Nat. Commun. 2012, 3, 917. [CrossRef]

10. Kao, C.-Y.; Tsai, Y.-R.; Chou, K.-S. Synthesis and characterization of the iron/copper composite as an electrode material for the rechargeable alkaline battery. J. Power Sources 2011, 196, 5746-5750. [CrossRef]

11. Sundar Rajan, A.; Ravikumar, M.K.; Priolkar, K.R.; Sampath, S.; Shukla, A.K. Carbonyl-Iron Electrodes for Rechargeable-Iron Batteries. Electrochem. Energy Technol. 2015, 1. [CrossRef]

12. Ravikumar, M.K.; Rajan, A.S.; Sampath, S.; Priolkar, K.R.; Shukla, A.K. In Situ Crystallographic Probing on Ameliorating Effect of Sulfide Additives and Carbon Grafting in Iron Electrodes. J. Electrochem. Soc. 2015, 162, A2339-A2350. [CrossRef]

13. Manohar, A.K.; Yang, C.; Malkhandi, S.; Prakash, G.K.S.; Narayanan, S.R. Enhancing the Performance of the Rechargeable Iron Electrode in Alkaline Batteries with Bismuth Oxide and Iron Sulfide Additives. J. Electrochem. Soc. 2013, 160, A2078-A2084. [CrossRef]

14. Yang, C.; Manohar, A.K.; Narayanan, S.R. A High-Performance Sintered Iron Electrode for Rechargeable Alkaline Batteries to Enable Large-Scale Energy Storage. J. Electrochem. Soc. 2017, 164, A418-A429. [CrossRef]

15. Manohar, A.K.; Yang, C.; Narayanan, S.R. The Role of Sulfide Additives in Achieving Long Cycle Life Rechargeable Iron Electrodes in Alkaline Batteries. J. Electrochem. Soc. 2015, 162, A1864-A1872. [CrossRef]

16. Yang, B.; Malkhandi, S.; Manohar, A.K.; Prakash, G.K.S.; Narayanan, S.R. Organo-sulfur molecules enable iron-based battery electrodes to meet the challenges of large-scale electrical energy storage. Energy Environ. Sci. 2014, 7, 2753-2763. [CrossRef]

17. Hang, B.T.; Watanabe, T.; Egashira, M.; Watanabe, I.; Okada, S.; Yamaki, J.-I. The effect of additives on the electrochemical properties of Fe/C composite for Fe/air battery anode. J. Power Sources 2006, 155, 461-469. [CrossRef]

18. Rajan, A.S.; Sampath, S.; Shukla, A.K. An in situ carbon-grafted alkaline iron electrode for iron-based accumulators. Energy Environ. Sci. 2014, 7, 1110-1116. [CrossRef]

19. Balasubramanian, T.S.; Shukla, A.K. Effect of metal-sulfide additives on charge/discharge reactions of the alkaline iron electrode. J. Power Sources 1993, 41, 99-105. [CrossRef]

20. Manohar, A.K.; Malkhandi, S.; Yang, B.; Yang, C.; Surya Prakash, G.K.; Narayanan, S.R. A High-Performance Rechargeable Iron Electrode for Large-Scale Battery-Based Energy Storage. J. Electrochem. Soc. 2012, 159, A1209-A1214. [CrossRef]

21. Lei, D.; Lee, D.C.; Magasinski, A.; Zhao, E.; Steingart, D.; Yushin, G. Performance Enhancement and Side Reactions in Rechargeable Nickel-Iron Batteries with Nanostructured Electrodes. ACS Appl. Mater. Interfaces 2016, 8, 2088-2096. [CrossRef]

22. Jiang, W.; Liang, F.; Wang, J.; Su, L.; Wu, Y.; Wang, L. Enhanced electrochemical performances of FeOx-graphene nanocomposites as anode materials for alkaline nickel-iron batteries. RSC Adv. 2014, 4, 15394-15399. [CrossRef]

23. Ito, A.; Zhao, L.; Okada, S.; Yamaki, J.-I. Synthesis of nano- $\mathrm{Fe}_{3} \mathrm{O}_{4}$-loaded tubular carbon nanofibers and their application as negative electrodes for Fe/air batteries. J. Power Sources 2011, 196, 8154-8159. [CrossRef]

24. Shangguan, E.; Guo, L.; Li, F.; Wang, Q.; Li, J.; Li, Q.; Chang, Z.; Yuan, X.-Z. FeS anchored reduced graphene oxide nanosheets as advanced anode material with superior high-rate performance for alkaline secondary batteries. J. Power Sources 2016, 327, 187-195. [CrossRef]

25. Shangguan, E.; Li, F.; Li, J.; Chang, Z.; Li, Q.; Yuan, X.-Z.; Wang, H. FeS/C composite as high-performance anode material for alkaline nickel-iron rechargeable batteries. J. Power Sources 2015, 291, 29-39. [CrossRef] 
26. Hang, B.T.; Watanabe, T.; Eashira, M.; Watanabe, I.; Okada, S.; Yamaki, J.-I. Comparative Study of $\mathrm{Fe}_{2} \mathrm{O}_{3}$-Nanoloaded Carbon and $\mathrm{Fe}_{2} \mathrm{O}_{3}$-Nano/Carbon Mixed Composites for Iron-Air Battery Anodes. Electrochem. Solid-State Lett. 2005, 8, A476-A480. [CrossRef]

27. Hang, B.T.; Watanabe, T.; Eashira, M.; Okada, S.; Yamaki, J.-I.; Hata, S.; Yoon, S.-H.; Mochida, I. The electrochemical properties of $\mathrm{Fe}_{2} \mathrm{O}_{3}$-loaded carbon electrodes for iron-air battery anodes. J. Power Sources 2005, 150, 261-271. [CrossRef]

28. Hang, B.T.; Eashira, M.; Watanabe, I.; Okada, S.; Yamaki, J.-I.; Yoon, S.-H.; Mochida, I. The effect of carbon species on the properties of Fe/C composite for metal-air battery anode. J. Power Sources 2005, 143, 256-264. [CrossRef]

29. Kao, C.Y.; Chou, K.S. Iron/carbon-black composite nanoparticles as an iron electrode material in a paste type rechargeable alkaline battery. J. Power Sources 2010, 195, 2399-2404. [CrossRef]

30. Kim, T.; Ohata, Y.; Kim, J.; Rhee, C.K.; Miyawaki, J.; Yoon, S.-H. Fe nanoparticle entrained in tubular carbon nanofiber as an effective electrode material for metal-air batteries: A fundamental reason. Carbon 2014, 80, 698-707. [CrossRef]

31. Huang, K.-C.; Chou, K.-S. Microstructure changes to iron nanoparticles during discharge/charge cycles. Electrochem. Commun. 2007, 9, 1907-1912. [CrossRef]

32. Guo, C.X.; Li, C.M. Molecule-confined FeOx nanocrystals mounted on carbon as stable anode material for high energy density nickel-iron batteries. Nano Energy 2017, 42, 166-172. [CrossRef]

33. Wu, X.; Wu, H.B.; Xiong, W.; Le, Z.; Sun, F.; Liu, F.; Chen, J.; Zhu, Z.; Lu, Y. Robust iron nanoparticles with graphitic shells for high-performance Ni-Fe battery. Nano Energy 2016, 30, 217-224. [CrossRef]

34. Paulraj, A.R.; Kiros, Y.; Skårman, B.; Vidarsson, H. Core/Shell Structure Nano-Iron/Iron Carbide Electrodes for Rechargeable Alkaline Iron Batteries. J. Electrochem. Soc. 2017, 164, A1665-A1672. [CrossRef]

35. Chamoun, M.; Skårman, B.; Vidarsson, H.; Smith, R.I.; Hull, S.; Lelis, M.; Milcius, D.; Noréus, D. Stannate Increases Hydrogen Evolution Overpotential on Rechargeable Alkaline Iron Electrodes. J. Electrochem. Soc. 2017, 164, A1251-A1257. [CrossRef]

36. Kiros, Y.; Pirjamali, M.; Bursell, M. Oxygen reduction electrodes for electrolysis in chlor-alkali cells. Electrochim. Acta 2006, 51, 3346-3350. [CrossRef]

37. Pirjamali, M.; Kiros, Y. Effects of carbon pretreatment for oxygen reduction in alkaline electrolyte. J. Power Sources 2002, 109, 446-451. [CrossRef]

38. Svengren, H.; Chamoun, M.; Grins, J.; Johnsson, M. Water Splitting Catalysis Studied by using Real-Time Faradaic Efficiency Obtained through Coupled Electrolysis and Mass Spectrometry. ChemElectroChem 2018, 5, 44-50. [CrossRef]

39. Li, F.; Pan, Y.; Wang, H.; Huang, X.; Zhang, Q.; Peng, Z.; Tang, Y. Core-Bishell Fe-Ni@Fe $\mathrm{O}_{4} @ \mathrm{C}$ Nanoparticles as an Advanced Anode for Rechargeable Nickel-Iron Battery. J. Electrochem. Soc. 2017, 164, A1333-A1338. [CrossRef]

40. Wang, B.; Liu, T.; Liu, A.; Liu, G.; Wang, L.; Gao, T.; Wang, D.; Zhao, X.S. A Hierarchical Porous C@LiFePO4/Carbon Nanotubes Microsphere Composite for High-Rate Lithium-Ion Batteries: Combined Experimental and Theoretical Study. Adv. Energy Mater. 2016, 6, 1600426. [CrossRef]

41. Li, R.; Wang, Y.; Zhou, C.; Wang, C.; Ba, X.; Li, Y.; Huang, X.; Liu, J. Carbon-Stabilized High-Capacity Ferroferric Oxide Nanorod Array for Flexible Solid-State Alkaline Battery-Supercapacitor Hybrid Device with High Environmental Suitability. Adv. Funct. Mater. 2015, 25, 5384-5394. [CrossRef]

42. Li, F.; Shangguan, E.; Li, J.; Li, L.; Yang, J.; Chang, Z.; Li, Q.; Yuan, X.-Z.; Wang, H. Influence of annealing temperature on the structure and electrochemical performance of the $\mathrm{Fe}_{3} \mathrm{O}_{4}$ anode material for alkaline secondary batteries. Electrochim. Acta 2015, 178, 34-44. [CrossRef]

43. Annamalai, A.; Shinde, P.S.; Jeon, T.H.; Lee, H.H.; Kim, H.G.; Choi, W.; Jang, J.S. Fabrication of superior $\alpha-\mathrm{Fe}_{2} \mathrm{O}_{3}$ nanorod photoanodes through ex-situ Sn-doping for solar water splitting. Sol. Energy Mater. Sol. Cells 2016, 144, 247-255. [CrossRef]

44. Xie, K.; Lu, Z.; Huang, H.; Lu, W.; Lai, Y.; Li, J.; Zhou, L.; Liu, Y. Iron supported C@Fe $\mathrm{O}_{4}$ nanotube array: A new type of 3D anode with low-cost for high performance lithium-ion batteries. J. Mater. Chem. 2012, 22, 5560-5567. [CrossRef]

45. Bokobza, L.; Bruneel, J.-L.; Couzi, M. Raman Spectra of Carbon-Based Materials (from Graphite to Carbon Black) and of Some Silicone Composites. C 2015, 1, 77-94. [CrossRef] 
46. Wu, K.-H.; Wang, D.-W.; Su, D.-S. An Extension to the Analytical Evaluation of the Oxygen Reduction Reaction Based On the Electrokinetics on a Rotating Ring-Disk Electrode. ChemElectroChem 2016. [CrossRef]

47. Wang, B.; Xie, Y.; Liu, T.; Luo, H.; Wang, B.; Wang, C.; Wang, L.; Wang, D.; Dou, S.; Zhou, Y. LiFePO 4 quantum-dots composite synthesized by a general microreactor strategy for ultra-high-rate lithium ion batteries. Nano Energy 2017, 42, 363-372. [CrossRef]

48. Wang, B.; Al Abdulla, W.; Wang, D.; Zhao, X.S. A three-dimensional porous LiFePO4 cathode material modified with a nitrogen-doped graphene aerogel for high-power lithium ion batteries. Energy Environ. Sci. 2015, 8, 869-875. [CrossRef]

49. Hansal, W.E.G.; Halmdienst, M.; Hansal, S.; Boussaboua, I.; Darchen, A. Influence of pulse plating parameters on morphology and hardness of pure tin deposit. Trans. IMF 2008, 86, 115-121. [CrossRef]

50. Bani Hashemi, A.; La Mantia, F. Cell Design for Electrochemical Characterizations of Metal-Ion Batteries in Organic and Aqueous Electrolyte. Anal. Chem. 2016, 88, 7916-7920. [CrossRef]

(C) 2018 by the authors. Licensee MDPI, Basel, Switzerland. This article is an open access article distributed under the terms and conditions of the Creative Commons Attribution (CC BY) license (http://creativecommons.org/licenses/by/4.0/). 